\title{
Front Matter: Volume 10340
}

, "Front Matter: Volume 10340," Proc. SPIE 10340, International Conference on Biophotonics V, 1034001 (29 April 2017); doi: 10.1117/12.2280085

SPIE. Event: International Conference on Biophotonics V, 2017, Perth, Australia 


\title{
PROGRESS IN BIOMEDICAL OPTICS AND IMAGING
}

\section{International Conference on Biophotonics V}

\author{
David D. Sampson \\ Dennis L. Matthews \\ Jürgen Popp \\ Halina Rubinsztein-Dunlop \\ Brian C. Wilson \\ Editors
}

30 April-1 May 2017

Perth, Australia

Organized by

Optical+Biomedical Engineering Laboratory, The University of Western Australia (Australia)

Sponsored by

The University of Western Australia (Australia)

ARC Centre for Nanoscale Biophotonics (Australia)

ARC Centre for Advanced Molecular Imaging (Australia)

Engineers Enterprise (Australia)

Micron Optics, Inc. (United States)

Published by

SPIE 
The papers included in this volume were part of the technical conference cited on the cover and title page. Papers were selected and subject to review by the editors and conference program committee. Some conference presentations may not be available for publication. The papers published in these proceedings reflect the work and thoughts of the authors and are published herein as submitted. The publisher is not responsible for the validity of the information or for any outcomes resulting from reliance thereon.

Please use the following format to cite material from these proceedings:

Author(s), "Title of Paper," in International Conference on Biophotonics V, edited by David D. Sampson, Dennis L. Matthews, Jürgen Popp, Halina Rubinsztein-Dunlop, Brian C. Wilson, Proceedings of SPIE Vol. 10340 (SPIE, Bellingham, WA, 2017) Seven-digit Article CID Number.

ISSN: 1605-7422

ISSN: 2410-9045 (electronic)

ISBN: 9781510611252

ISBN: 9781510611269 (electronic)

Published by

SPIE

P.O. Box 10, Bellingham, Washington 98227-0010 USA

Telephone +1 3606763290 (Pacific Time) · Fax +1 3606471445

SPIE.org

Copyright (C) 2017, Society of Photo-Optical Instrumentation Engineers.

Copying of material in this book for internal or personal use, or for the internal or personal use of specific clients, beyond the fair use provisions granted by the U.S. Copyright Law is authorized by SPIE subject to payment of copying fees. The Transactional Reporting Service base fee for this volume is $\$ 18.00$ per article (or portion thereof), which should be paid directly to the Copyright Clearance Center (CCC), 222 Rosewood Drive, Danvers, MA 01923. Payment may also be made electronically through CCC Online at copyright.com. Other copying for republication, resale, advertising or promotion, or any form of systematic or multiple reproduction of any material in this book is prohibited except with permission in writing from the publisher. The CCC fee code is $1605-7422 / 17 / \$ 18.00$.

Printed in the United States of America.

Publication of record for individual papers is online in the SPIE Digital Library.

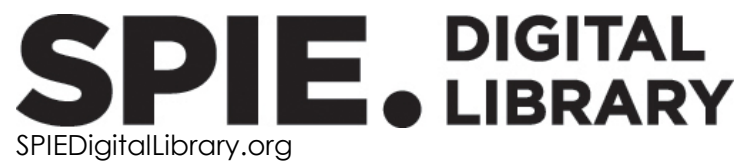

Paper Numbering: Proceedings of SPIE follow an e-First publication model, with papers published first online and then in print. Papers are published as they are submitted and meet publication criteria. A unique citation identifier (CID) number is assigned to each article at the time of the first publication. Utilization of CIDs allows articles to be fully citable as soon as they are published online, and connects the same identifier to all online, print, and electronic versions of the publication. SPIE uses a seven-digit CID article numbering system in which:

- The first five digits correspond to the SPIE volume number.

- The last two digits indicate publication order within the volume using a Base 36 numbering

system employing both numerals and letters. These two-number sets start with 00, 01, 02, 03, 04, $05,06,07,08,09,0 A, 0 B \ldots$. 0Z, followed by 10-1Z, 20-2Z, etc.

The CID Number appears on each page of the manuscript. The complete citation is used on the first page, and an abbreviated version on subsequent pages. 


\title{
Contents
}

\author{
$\checkmark \quad$ Authors \\ vii Conference Committee \\ xi Introduction \\ xiii Poster Presentation Files
}

INTERNATIONAL CONFERENCE ON BIOPHOTONICS V

1034004 Optical pre-screening in breast screening programs: Can we identify women who benefit most from limited mammography resources? [10340-3]

1034006 Developing a treatment planning process and software for improved translation of photodynamic therapy [10340-5]

1034009 Aggregation-based rapid detection of Enterovirus 71 using surface-enhanced Raman spectroscopy [10340-8]

$10340 \mathrm{OF} \quad$ Non-linear multimodal imaging for disease diagnostics and treatment monitoring [10340-15]

10340 OJ Imaging galectin-3 dependent endocytosis with lattice light-sheet microscopy [10340-19]

10340 OW Functionalized gold nanostars for label-free detection of PKA phosphorylation using surface-enhanced Raman spectroscopy [10340-33]

10340 0X Optical fibre sensing at the interface between tissue and medical device [10340-34]

1034011 A gold nanostar-based SERS platform for point-of-care diagnostics of carbapenemaseproducing enterobacteriacae [10340-38]

1034012 Optical fibre sensing during critical care [10340-39]

1034013 Physical basics of endovenous laser treatment and potential of innovative developments [10340-40]

1034014 Photodynamic diagnosis and related optical techniques for the management of malignant glioma [10340-41]

1034015 Sheet-like chiro-optical material designs based C(Y) surfaces [10340-42] 
Proc. of SPIE Vol. $103401034001-4$

Downloaded From: https://www.spiedigitallibrary.org/conference-proceedings-of-spie on 26 Apr 2023 Terms of Use: https://www.spiedigitallibrary.org/terms-of-use 


\section{Authors}

Numbers in the index correspond to the last two digits of the seven-digit citation identifier (CID) article numbering system used in Proceedings of SPIE. The first five digits reflect the volume number. Base 36 numbering is employed for the last two digits and indicates the order of articles within the volume. Numbers start with 00, 01, 02, 03, 04, 05, 06, 07, 08, 09, OA, OB...0Z, followed by 10-12, 20-2Z, etc.

Ang, Swee Kim, 09

Baek, Jongho, 0J

Betz, V., 06

Beyer, W., 14

Bocklitz, Thomas, OF

Cassidy, J., 06

Chan, Jingqi, 09

Chernavskaia, Olga, OF

Chu, Justin Jang Hann, 09

Coelho, Simao, OJ

Correia, R., OX, 12

Esipova, A., 13

Evans, D., 12

Gaus, Katharina, OJ

Hayes-Gill, B. R., OX, 12

$\mathrm{He}$, Shuai, 09, OW, 11

Hernandez, F. U., OX, 12

Hess, O., 15

Heuke, Sandro, OF

Hromadka, J., 12

Johannes, Ludger, 0J

Kah, James Chen-Yong, 09, 0W, 11

Kang, Wei Cherng Malvin, 11

Korposh, S., OX, 12

Lee, S.-W., 12

Lilge, Lothar, 04, 06

Lim, Yean Jin, 0J

Loshchenov, Maxim, 04

Lou, Jieqiong, OJ

Lukić, Aleksandar, OF

Markwardt, N., 14

Meyer, Tobias, OF

Mohd Hazlan, N. N., 12

Morgan, S. P., OX, 12

Nicovich, Philip R., OJ

Norris, A., OX, 12

Peake, Rachel, 04

Piotrowski, Marek, 09, 11

Popp, Jürgen, OF

Reyes, Miguel, 09

Robisch, A.-M., 15

Rühm, A., 14

Saba, M., 15

Schmedt, C. G., 13

Schmitt, Michael, OF

Schröder-Turk, G. E., 15

Seidlitz, Silvia, OJ

Sinha, R., OX

Sroka, R., 13, 14
Stepp, H., 14

Stone, Jennifer, 04

Talbot, S., OX

Thiel, M., 15

Teo, Woon Pei Jeanette, 11

Walter, Jane, 04

Wang, T., 12

Wong, Yen Lynn, 11

Wunder, Christian, OJ

$\mathrm{XU}, \mathrm{Y} ., 06$

Zheng, Z., 06

Zhilkin, Vladimir, 04 
Proc. of SPIE Vol. $103401034001-6$

Downloaded From: https://www.spiedigitallibrary.org/conference-proceedings-of-spie on 26 Apr 2023 Terms of Use: https://www.spiedigitallibrary.org/terms-of-use 


\title{
Conference Committee
}

\author{
Conference Chair
}

David D. Sampson, The University of Western Australia (Australia)

Executive Committee

David D. Sampson, The University of Western Australia (Australia)

Dennis L. Matthews, University of California, Davis (United States)

Jürgen Popp, Leibniz Institute of Photonic Technology (Germany)

Halina Rubinsztein-Dunlop, University of Queensland (Australia)

Brian C. Wilson, Princess Margaret Cancer Centre (Canada)

International Advisory Committee

Stefan Anderssen-Engels, Tyndall National Institute (Ireland)

Stephen A. Boppart, University of Illinois at Urbana-Champaign (United States)

Francesco Baldini, Istituto di Fisica Applicata "Nello Carrara" (Italy)

Brett E. Bouma, Harvard Medical School (United States)

Zhongping Chen, University of California, Irvine (United States)

Arthur Chiou, National Yang Ming University (Taiwan)

Wonshik Choi, Korea University (Korea, Republic of)

Johannes de Boer, Vrije University (Netherlands)

Kishan Dholakia, University of St Andrews (United Kingdom)

Alberto Diaspro, Istituto Italiano di Tecnologia (Italy)

Daniel S. Elson, Imperial College London (United Kingdom)

Paul French, Imperial College London (United Kingdom)

Brant Gibson, RMIT University (Australia)

Ewa Goldys, Macquarie University (Australia)

Min Gu, RMIT University (Australia)

John Harvey, The University of Auckland (New Zealand)

Elizabeth Hillman, Columbia University (United States)

Christoph Hitzenberger, Medical University of Vienna (Austria)

Robert Huber, Max Planck Institute of Biochemistry (Germany)

Mark Hutchinson, The University of Adelaide (Australia)

Steven Jacques, Oregon Health \& Science University (United States)

Fu-Jen Kao, National Yang-Ming University (Taiwan)

Byoung Yoon Kim, Korea Advanced Institute of Science \& Technology

(Korea, Republic of)

Karsten Koenig, Saarland University (Germany)

Kirill Larin, University of Houston (United States)

Martin Leahy, National University Galway (Ireland) 
Rainer Leitgeb, Medical University of Vienna (Austria)

Richard Levenson, University of California, Davis (United States)

Lothar Lilge, University Health Network (Canada)

Qingming Luo, Huazhong University of Science and Technology

(China)

Anita Mahadevan-Jansen, Vanderbilt University (United States)

Susana Marcos, Instituto de Optica (Spain)

Laura Marcu, University of California, Davis (United States)

Robert McLaughlin, The University of Adelaide (Australia)

Anna-Grazia Mignani, Istituto di Fisica Applicata "Nello Carrara" (Italy)

Tanya Monro, University of South Australia (Australia)

Kentaro Nakamura, Tokyo Institute of Technology (Japan)

Francesco S. Pavone, European Laboratory for Non-linear

Spectroscopy (Italy)

Roberto Pini, University of Florence (Italy)

Adrian Podoleanu, University of Kent (United Kingdom)

Gabriel Popescu, University of Illinois at Urbana-Champaign

(United States)

Alexander Priezzhev, Lomonosov Moscow State University

(Russian Federation)

Jannick Rolland, University of Rochester (United States)

Natalia Shakhova, University Alaska Fairbanks (United States)

Colin Sheppard, Istituto Italiano di Tecnologia (Italy)

Peter So, Massachusetts Institute of Technology (United States)

Ronald Sroka, University Hospital Munich (Germany)

Katarina Svanberg, Lund University (Sweden)

Peter Török, University College London (United Kingdom)

Bruce Tromberg, University of California, Irvine (United States)

Kevin Tsia, Hong Kong University (Hong Kong, China)

Valery Tuchin, Saratov State University (Russian Federation)

Ton van Leeuwen, University of Amsterdam (The Netherlands)

Gijs van Soest, Erasmus Medical Centre (The Netherlands)

Alex Vitkin, University of Toronto (Canada)

Ruikang K. Ricky Wang, University of Washington (United States)

Tony Wilson, University of Oxford (United Kingdom)

Maciej Wojtkowski, Nicolaus Copernicus University (Poland)

Victor X. D. Yang, Ryerson University (Canada)

Yoshiaki Yasuno, University of Tsukuba (Japan)

Soek Hyun A. Yun, Harvard Medical School (United States)

Andrei Zvyagin, Macquarie University (Australia)

Programme Committee

Warwick Bowen, University of Queensland (Australia)

Kenneth Crozier, University of Melbourne (Australia)

Vincent Daria, Australian National University (Australia)

Heike Ebendorff-Heidepriem, The University of Adelaide (Australia) 
Katharina Gaus, University of New South Wales (Australia)

Brant Gibson, RMIT University (Australia)

Ewa Goldys, Macquarie University (Australia)

Min Gu, RMIT University (Australia)

Mark Hutchinson, The University of Adelaide (Australia)

Dayong Jin, University of Technology Sydney (Australia)

W. M. Steve Lee, Australian National University (Australia)

Robert McLaughlin, The University of Adelaide (South Australia)

Aleksandar Rakic, University of Queensland (Australia)

Ann Roberts, University of Melbourne (Australia)

Cather Simpson, The University of Auckland (New Zealand)

Frederique Vanholsbeeck, The University of Auckland (New Zealand)

Michael Withford, Macquarie University (Australia)

Andrei Zvyagin, Macquarie University (Australia)

Session Chairs

1 How to Set a Big Picture Biophotonics Agenda

Laura Marcu, University of California, Davis (United States)

2 In-vivo Non-invasive Retinal Vessel and Blood Flow Imaging:

Biophotonic Advances and Clinical Applications

Fred K. Chen, Lions Eye Institute (Australia)

3 Tumour Margin Identification: Critiquing Technologies

Stephen A. Boppart, University of Illinois Urbana Champaign (United States)

$4 \quad$ Hot Posters

Philip Wijesinghe, The University of Western Australia (Australia)

Danuta M. Sampson, Lions Eye Institute (Australia)

5 Challenges in Translation: Models to Promote Translation

Jürgen Popp, Leibniz Institute of Photonic Technology (Germany)

6 SPARK Co-Lab, Training People to Identify a Commercial Pathway for Unmet Needs

Peter Santa Maria, The University of Western Australia (Australia)

$7 \quad$ Neurophotonics

Anita Mahadevan-Jansen, Vanderbilt University (United States)

8 Radical New Ideas in Biophotonics

Kishan Dholakia, University of St Andrews (United Kingdom) 
Proc. of SPIE Vol. 10340 1034001-10 Downloaded From: https://www.spiedigitallibrary.org/conference-proceedings-of-spie on 26 Apr 2023
Terms of Use: https://www.spiedigitallibrary.org/terms-of-use 


\title{
Introduction
}

Welcome to the 5th International Conference on Biophotonics (ICOB V) in Perth, Western Australia, 30 April-1 May 2017. ICOB $\vee$ continues the success of the previous meetings held in Sacramento, Ottawa, Jena, and Florence. The conference has a strong theme of engagement with medical end users. The ICOB $V$ is held over two days as a stand-alone meeting and, on the third day, combines with the opening plenary session of science on the Swan, a broadbased biomedical research conference held annually in Perth.

ICOB $\vee$ continues the tradition of bringing together opinion leaders in the field to consider where the field is going and what opportunities there are to work together. Key in this endeavor are end users of biophotonics. This year, co-location and running back-to-back with Science on the Swan presents an exceptional opportunity to engage with medical researchers and translators.

ICOB $\vee$ is run as a largely single-stream meeting with sessions led by leaders in different aspects of biophotonics research and translation. Ample time is set aside for discussion and, in a new initiative, session leaders will convene the production of white papers after the conference summarizing the state of the field in their area. These papers will be published in the Journal of Biomedical Optics. The technical content in this meeting is largely delivered via a poster session with an associated Hot Poster session in which selected presenters deliver short previews of their work. The poster session involves strong participation of early-career and postgraduate researchers, including in its organization, the awarding of poster prizes. There is an associated exhibition to avail researchers with the chance to observe the latest commercial technical developments, and several sessions consider opportunities for entrepreneurship in biophotonics and pathways for translation.

The conference, held in Perth's port and historic cultural centre of Fremantle, provides an ideal venue for offsite events and interactions all within a short walk of the conference's venue, the historic Esplanade Hotel.

We hope the delegates find ICOB $\vee$ an event to remember, and that these proceeedings help capture some part of that.

\author{
David D. Sampson \\ Dennis L. Matthews \\ Jürgen Popp \\ Halina Rubinsztein-Dunlop \\ Brian C. Wilson
}


Proc. of SPIE Vol. 10340 1034001-12 Downloaded From: https://www.spiedigitallibrary.org/conference-proceedings-of-spie on 26 Apr 2023
Terms of Use: https://www.spiedigitallibrary.org/terms-of-use 


\section{ICOB 2017 Posters}

The following papers are published on the SPIE Digital Library only.

1034002 Multi-modal spectroscopic imaging with synchrotron light to study mechanisms of brain disease [10340-1]

K. L. Summers, N. Fimognari, A. Hollings, M. Kiernan, V. Lam, R. J. Tidy, R. Takechi,

G. N. George, I. J. Pickering, J. C. Mamo, H. H. Harris, M. J. Hackett, Curtin Univ. (Australia)

10340 OB Dispersion mapping as a simple post-processing step of standard Fourier domain Optical Coherence Tomography (OCT) data [10340-10]

S. Kolenderska, B. Bräuer, F. Vanholsbeeck, The Univ. of Auckland (New Zealand)

1034010 Optical coherence elastography for cellular-scale stiffness imaging of mouse aorta [10340-37]

P. Wijesinghe, N. J. Johansen, A. Curatolo, D. D. Sampson, R. Ganss, B. F. Kennedy, The Univ. of Western Australia (Australia)

1034016 Evaluation of changes in birefringence for samples subjected to various stress sources measured with polarization-sensitive OCT [10340-43]

K. Karnowski, Q. Li, Optical+Biomedical Engineering Lab., The Univ. of Western Australia (Australia); M. Villiger, Harvard Medical School (United States) and Massachusetts General Hospital, Wellman Ctr. for Photomedicine (United States); D. D. Sampson,

Optical+Biomedical Engineering Lab., The Univ. of Western Australia (Australia) and The Univ. of Western Australia (Australia)

1034017 Axial length variation impacts on retinal vessel density and foveal avascular zone area measurement using optical coherence tomography angiography [10340-44]

D. M. Sampson, The Univ. of Western Australia (Australia) and Lions Eye Institute (Australia); P. Gong, The Univ. of Western Australia (Australia); D. An, Zhejiang Univ. (China); M. Menghini, Sir Charles Gairdner Hospital (Australia); A. Hansen, The Univ. of Western Australia (Australia); D. A. Mackey, The Univ. of Western Australia (Australia) and Lions Eye Institute (Australia); D. D. Sampson, The Univ. of Western Australia (Australia); F. K. Chen, The Univ. of Western Australia (Australia), Lions Eye Institute (Australia), and Royal Perth Hospital (Australia)

1034018 Ex-vivo imaging of blood and lymphatic vessels in conjunctiva using optical coherence tomography [10340-45]

P. Gong, K. Karnowski, Optical+Biomedical Engineering Lab., The Univ. of Western Australia (Australia); P. Yu, D. An, D.-Y. Yu, The Univ. of Western Australia (Australia) and Lions Eye Institute (Australia); D. M. Sampson, Optical+Biomedical Engineering Lab., The Univ. of

Western Australia (Australia) and The Univ. of Western Australia (Australia) 
1034019 Local birefringence of the anterior segment of the human eye in a single capture with a full range polarisation-sensitive optical coherence tomography [10340-46]

Q. Li, K. Karnowski, Optical+Biomedical Engineering Lab., The Univ. of Western Australia (Australia); M. Villiger, Harvard Medical School (United States) and Massachusetts General Hospital, Wellman Ctr. for Photomedicine (United States); D. D. Sampson, Optical+Biomedical Engineering Lab., The Univ. of Western Australia (Australia) and The Univ. of Western Australia (Australia)

$103401 \mathrm{~A} \quad$ Ultrafast laser scanning cellular microscopy by spatiotemporally encoded virtual sources [10340-47]

W. Yan, J. Wu, K. K. Y. Wong, K. K. Tsia, The Univ. of Hong Kong (Hong Kong, China)

10340 1B Preliminary results on in-vivo imaging of upper airway inhalation injuries using anatomical optical coherence tomography [10340-48]

A. Phan, K. Karnowski, Q. Lee, P. Fejes, Optical+Biomedical Engineering Lab., The Univ. of Western Australia (Australia); B. Quirk, R. McLaughlin, Ctr. for Nanoscale Biophotonics, The Univ. of Adelaide (Australia); F. M. Wood, Burns Service of Western Australia, Royal Perth Hospital (Australia) and Burns Injury Research Unit, School of Surgery, The Univ. of Western Australia (Australia); D. D. Sampson, Optical+Biomedical Engineering Lab., The Univ. of Western Australia (Australia) and The Univ. of Western Australia (Australia)

10340 1E Optical coherence tomography multichannel probe design for speckle reduction [10340-51]

D. Cui, E. Bo, Y. Luo, X. Liu, X. Wang, S. Chen, X. Yu, S. Chen, P. Shum, L. Liu, Nanyang Technological Univ. (Singapore)

$103401 \mathrm{G} \quad$ Evaluating changes in brain vasculature of murine embryos in utero due to maternal alcohol consumption using optical coherence tomography [10340-53]

R. Raghunathan, C. Wu, M. Singh, C. Liu, Univ. of Houston (United States); R. C. Miranda, Texas A\&M Health Science Ctr. (United States); K. V. Larin, Univ. of Houston (United States) 